\title{
Soil quality regime in relation to land cover and slope position across a highly modified slope landscape
}

\author{
Bo-Jie FU, ${ }^{1 \star}$ Shi-Liang LIU, ${ }^{2}$ Li-Ding CHEN, ${ }^{1}$ Yi-He LÜ ${ }^{1}$ and Jun $\mathrm{QIU}^{1}$ \\ ${ }^{1}$ Key Laboratory of Systems Ecology, Research Center for Eco-Environmental Sciences, Chinese Academy of Sciences, P.O. BOX 2871, Beijing \\ 100085, China and ${ }^{2}$ Institute of Environmental Sciences, Beijing Normal University, 100875, China
}

\begin{abstract}
Vegetation and land-use mosaics of shrub land, grassland, farmland and reforested land are characteristic for residential areas of the Wolong nature reserve in Sichuan province, southwest China. The patterns represent a stage in long-term human disturbance and natural secondary succession since deforestation. The aim of this paper was to elucidate the soil-land cover types, soil-slope position relationships on a typical disturbed slope in the humid mountainous region. Soils were taken from four typical land cover types (shrub land, grassland, farmland and reforested land) under four slope positions (upper slope, middle slope, lower slope, foot slope) to study the distribution of soil nutrients and moisture on the transect scales of the slope. To elucidate the influence of land-use and slope position on soil quality, two integrated quantitative indexes were developed to compare soil quality under different land-use types $(Q I)$ and under different slope positions (PI). The results showed shrub land had the highest $Q I$ value, while the $Q I$ of reforested land and farmland had lower values. Foot slopes and upper slopes had higher soil quality levels compared to middle slopes and lower slopes. The results indicated that on the slope scale shrub land had high soil quality levels. The results also suggested that in the area of China where the climate favors secondary succession, 'leave nature as it is' is a better choice than the policy 'change farmland to forest land'.
\end{abstract}

Key words: land-use; principal component analysis; slope position; soil nutrients; soil quality.

\section{Introduction}

Land cover changes may influence many natural phenomena and ecological processes, including soil nutrient and soil water change ( $\mathrm{Fu}$ et al. 1999, 2000). Characterizing spatial variability and distribution of soil nutrients in relation to site characteristics including climate, vegetation, slope position and other variables is critical for understanding how ecosystems work (Townsend et al. 1995) and assessing the effects of future land-use change on nutrients (Kosmas et al. 2000). Much attention is paid to nutrient variation across landscapes (Benning \& Seastedt 1995). Soil nutrient status can be changed where forest is cleared for agricultural cultivation, allowed to revert to natural vegetation or replanted to perennial vegetation (Lepsch et al. 1994; Moran et al. 2000; Fu et al. 2001). Differences in soil formation along a hill slope result in differences in soil properties (Brubaker et al. 1993), which can affect the pattern of plant production, litter production and decomposition.

During the past 50 years, disturbance to vegetation heterogeneity and fragmentation as a result of increas- ing human demand for firewood, timber and food crops in the residential area of mountains in the upper reaches of the Yangtze River has received extensive attention (An et al. 1997). Restoration of vegetation depends on improving not only species diversity but also soil conditions. Increasing human disturbance and past deforestation makes Wolong nature reserve in Sichuan province a typical and interesting area for an integrated analysis of soil quality change in relation to land cover and slope position. But in past studies on land-use and cover changes, limited attention has been paid to soil quality and its deterioration after the changes (Jamalam et al. 1998). In addition, single soil property evaluations, such as, changes in soil organic matter, N, P and $\mathrm{K}$ were usually emphasized, and much less attention was paid to a comprehensive assessment of soil quality changes (Wang \& Gong 1998). Integrated and simple comparison methods of soil quality evaluation under

\footnotetext{
*Author to whom correspondence should be addressed. Email: bfu@mail.rcees.ac.cn

Received 5 May 2003, Accepted 16 June 2003.
} 
different land cover and slope position should be undertaken.

There is strong rational for predicting that land cover and slope position would have a significant influence on soil nutrient conditions. Research of different slope positions within the same slope is a reasonable way to study soil nutrient changes due to land cover changes and succession after deforestation. Due to the mountainous landform and the great soil variability across the large area of Wolong nature reserve, we selected a typical high-modified slope landscape for this study. The objectives of this study were to: (i) analyze the soil nutrients and moisture change in different land cover types and slope positions after deforestation at the slope scale; and (ii) to develop two integrated soil quality indexes of land cover type and slope position using different methods to quantify their effects on soil quality.

\section{Methods}

\section{Study area}

The study was conducted in Pitiaohe catchment of Wolong nature reserve $\left(103^{\circ} 58^{\prime} \mathrm{E}, 30^{\circ} 58^{\prime} \mathrm{N}\right)$, which lies in Sichuan province, southwestern China (Fig. 1). There are significant topographic variations. Mountains are steep, streams down cut deeply. The reserve was originally covered with primary forests of faxon fir (Abies fargesii var.Faxoniana) and masters larch (Larix mastersiana) and experienced extensive of deforestation and secondary succession. In the past 50 years, people living in the surrounding villages have often encroached upon and cultivated agricultural crops to meet the increasing demands for food, firewood, timber and other construction materials (Liu et al. 2002). These intense human activities have hampered the regeneration of existing residual vegetation and land-use forms have also changed drastically. Vegetation mosaics of heterogeneous grassland, shrub land, cultivated land and forest land are characteristic for the study area. The slope we selected was typical for the intense human disturbance and various forms of land covers. The land cover changed greatly due to cultivation, succession and reforestation.

The climate of the study area was interior mountain climate with pronounced wet and cool seasons. The mean annual temperature is $8.5 \pm 0.5^{\circ} \mathrm{C}$, while the mean annual precipitation is about $890 \pm 100 \mathrm{~mm}$. Relative humidity ranges between 75.5 and $84.8 \%$. The soil was classified as humic acrisols (FAO-UNESCO 1988).

\section{Soil sampling methods and processing}

We chose a typical slope with the relative elevation of approximately $350 \mathrm{~m}$ in the Wolong region and divided the slope into four positions according to their elevations and topography: upper slope (US), middle slope (MS), lower slope (LS) and foot slope (FS). The slope gradients of US, MS and LS were approximately 30$35^{\circ}$. The FS was approximately $3-5^{\circ}$. The slope faces south-east. Four different land-use types that had

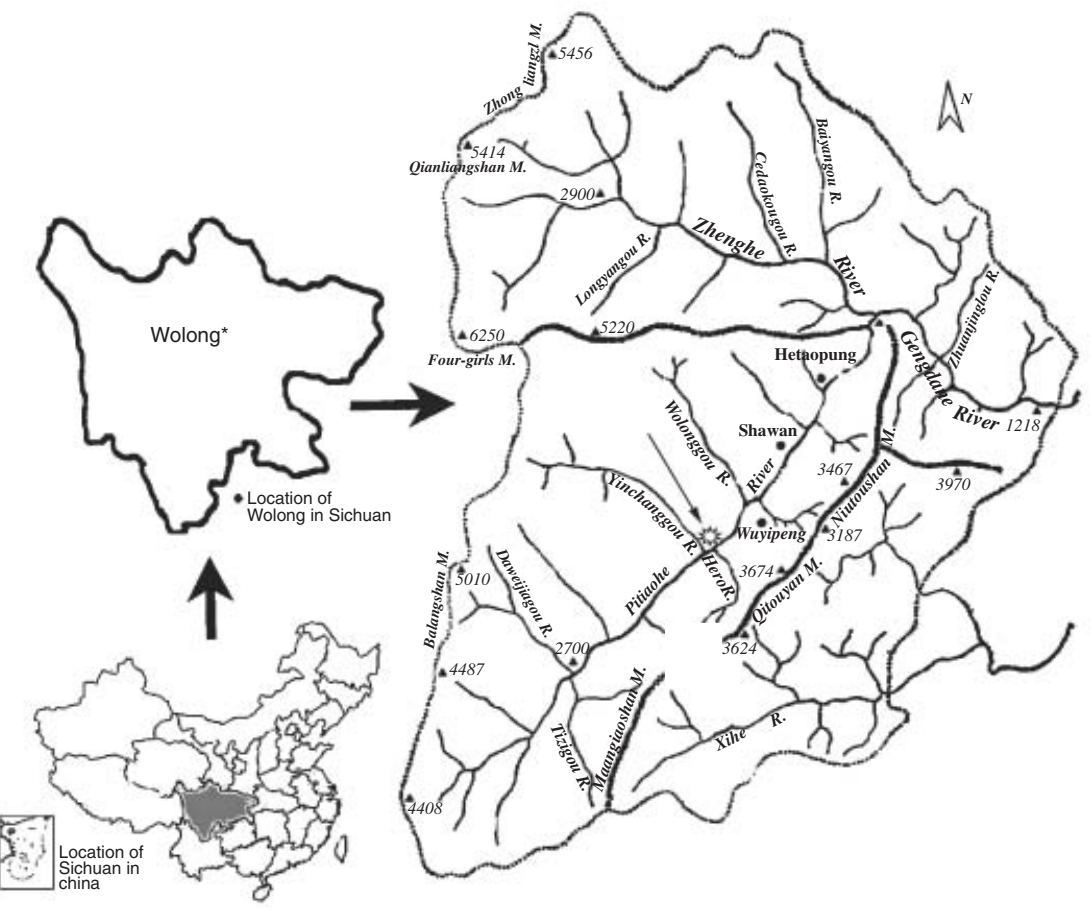

Fig. 1. Location of the study area. 
persisted for $>30$ years (except in some reforested lands where this was $<15$ years) were selected on each slope position and soils were sampled. The four types were:

1 Shrub land mainly with Chinese walnut (Fuglans cathayensis Dode), willow (Salix dissa Schneid) and rosebush (Rosa brunonii Lindl.), which was a successional community after deforestation.

2 Grassland mainly with mugwort wormwood (Artemisia spp.) and carex (Carex schneideri Nelmes, C. doniana Spreng.).

3 Reforested land with planted conifers, mainly dahurian larch (L. principis-rupprechtii Mayr).

4 Farmland under shifting cultivation (converted from forest or shrubs to grow corn (Zea mays L) and potatoes (Solanum tuberosum).

Three replicate soil samples from each sample site were homogenized by hand mixing and major live plant materials and pebbles were separated and discarded. Every land cover type of each slope position had two sample sites, giving a total of 32 from the whole slope.

A portable Time Domain Reflectometry (TDR) instrument was used to measure soil moisture content at $0-20 \mathrm{~cm}$ and $20-40 \mathrm{~cm}$ depth. At each site, soil moisture content was measured six times and then the average was calculated. Nutrient levels were determined for the surface soil samples $0-30 \mathrm{~cm}$ depth. The semimicro Kjeldahl method was used to determine the total soil nitrogen. Total phosphorus was determined colorimetrically after wet digestion with $\mathrm{H}_{2} \mathrm{SO}_{4}$ plus $\mathrm{HClO}_{4}$ (Parkinson \& Allen 1975) Available nitrogen was determined by the Cornfield method (alkaline hydrolysable nitrogen). Available potassium and available phosphorus were extracted with $3 \%\left(\mathrm{NH}_{4}\right)_{2} \mathrm{CO}_{3}$ solution. After filtering, the solution was measured by ICP-AES (Editorial Committee 1996). Soil organic matter (SOM) was determined by the $\mathrm{K}_{2} \mathrm{Cr}_{2} \mathrm{O}_{7}$ titration method after digestion (Nelson \& Sommers 1975). Total potassium (TK) was determined by atomic absorption spectrometer and soil bulk density (BD) was determined by the core method (Editorial Committee 1996). To improve the precision of the results, same samples were analyzed three times, and the average value was calculated.

ANOVA was used to compare the effects of different land-use types and slope positions on soil properties. The test of interaction effects of land-use and slope position was computed by the multivariate ANOVA. All the analyses were carried out through the SPSS program (SPSS, Chicago, Illinois, US, 1993).

\section{Calculation of soil quality index of land cover types}

A soil quality index $(Q I)$ is a useful way to determine land deterioration or improvement. Based on the assumption that different nutrients have different roles in maintaining soil quality, the $Q I$ was developed and calculated by selected soil factor membership values and their weight as in the following equation (Zhang et al. 1999):

$$
Q I=\sum_{i=1}^{n} W_{i} \times Q\left(x_{i}\right)
$$

where $W_{i}$ is the weight vector of $i$ soil quality factor and $Q\left(x_{i}\right)$ is the membership value of each soil quality factor.

The membership values $\left(Q\left(x_{i}\right)\right)$ were calculated by the ascending and descending functions listed below (Equations 2 and 3). A descending function was used for BD as its higher value often indicated soil deterioration, while an ascending function was used for soil nutrients (Li \& Zhang 1991).

$$
\begin{aligned}
& Q\left(x_{i}\right)=\left(x_{i j}-x_{i \min }\right) /\left(x_{i \max }-x_{i \min }\right) \\
& Q\left(x_{i}\right)=\left(x_{i \max }-x_{i}\right) /\left(x_{i \max }-x_{i \min }\right)
\end{aligned}
$$

where $x_{i j}$ is the value of the soil's physical and chemical properties that were selected for the soil quality; $x_{i \max }$ and $x_{\text {imin }}$ are the maximum and minimum value of the $i$ soil property.

There are many ways to assign the weights for each indicator. This includes experience, mathematical statistics or models (Wang 1994). In this study, principal component analysis (PCA) was used to determine the weights for each indicator. The cumulative percentage of principal soil quality components and values of component capacity score coefficient were calculated by the membership values $\left(Q\left(x_{i}\right)\right)$ using the sPSs program, and then the weights of the soil quality factors $\left(W_{i}\right)$ were calculated by the component capacity score coefficient (Equation 3).

$$
W_{i}=C_{i} / \sum_{i=1}^{n}\left(C_{i}\right)
$$

where $C_{i}$ is the component capacity score coefficient of $i$ soil quality factor.

\section{Calculation of soil quality in slope position}

An integrated relative value $(P I)$ was used to indicate the effects of slope position on soil quality. The difference between the mean values of individual soil properties from the four slope positions described previously were compared to the baseline values of soil properties from the upper slope position. These values were calculated and expressed as a percentage of the mean value of individual properties. These percent changes were then averaged across all soil properties to calculate the $P I$ values. We hypothesized that $P I$ is 0 at 
Table 1 Soil properties (0-30 cm depth) of different land cover types and their membership functions

\begin{tabular}{|c|c|c|c|c|c|c|c|c|c|}
\hline Land cover types & SM $(\%)$ & $\mathrm{BD}\left(\mathrm{g} \mathrm{cm}^{-3}\right)$ & SOM $(\%)$ & $\mathrm{TN}(\%)$ & $\mathrm{TP}(\%)$ & $\mathrm{TK}\left(\mathrm{g} \mathrm{kg}^{-1}\right)$ & $\mathrm{AN}\left(\mathrm{mg} \mathrm{kg}^{-1}\right)$ & $\mathrm{AP}\left(\mathrm{mg} \mathrm{kg}^{-1}\right)$ & $\mathrm{AK}\left(\mathrm{mg} \mathrm{kg}^{-1}\right)$ \\
\hline Shrub land & $\frac{16.28 \dagger}{1.000 \ddagger}$ & $\frac{0.76}{1.000}$ & $\frac{13.72}{1.000}$ & $\frac{0.76}{1.000}$ & $\frac{0.112}{1.000}$ & $\frac{22.6}{0}$ & $\frac{1330.6}{1.000}$ & $\frac{16.3}{1.000}$ & $\frac{323.4}{1.000}$ \\
\hline Grassland & $\frac{14.93}{0.413}$ & $\frac{0.98}{0.397}$ & $\frac{9.65}{0.503}$ & $\frac{0.51}{0.399}$ & $\frac{0.102}{0.481}$ & $\frac{23.8}{0.680}$ & $\frac{1165.9}{0.669}$ & $\frac{12.6}{0.270}$ & $\frac{166.7}{0.288}$ \\
\hline Farmland & $\frac{14.23}{0.105}$ & $\frac{1.13}{0}$ & $\frac{6.54}{0.123}$ & $\frac{0.36}{0.053}$ & $\frac{0.102}{0.527}$ & $\frac{24.4}{1.000}$ & $\frac{1036.6}{0.409}$ & $\frac{13.4}{0.428}$ & $\frac{103.41}{0}$ \\
\hline Reforested land & $\frac{13.98}{0}$ & $\frac{0.89}{0.637}$ & $\frac{5.54}{0}$ & $\frac{0.34}{0}$ & $\frac{0.092}{0}$ & $\frac{23.0}{0.193}$ & $\frac{833.3}{0}$ & $\frac{11.2}{0}$ & $\frac{161.1}{0.262}$ \\
\hline F-value & 0.323 & $3.42^{\star}$ & $8.77^{\star \star}$ & $2.74 \star$ & 0.87 & 0.08 & 1.49 & 1.21 & $4.31^{\star \star}$ \\
\hline
\end{tabular}

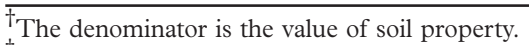

摘e numerator is its membership function value.

AK, available potassium; AN, available nitrogen; AP, available phosphorus; BD, bulk density; SM, soil moisture; SOM, soil organic carbon; TK, total potassium; TN, total nitrogen; TP, total phosphorus. $\mathrm{pH}$ measured in $1: 2.5$ soil-water suspensions.

${ }^{\star}$ Significant at the $5 \%$ level of probability. ${ }^{\star}$ Significant at the $1 \%$ level of probability.

Table 2 Soil properties $(0-30 \mathrm{~cm}$ depth) on different slope positions and the tests of interaction effects of land cover and slope position

\begin{tabular}{|c|c|c|c|c|c|c|c|c|c|}
\hline Transect position & $\begin{array}{l}\mathrm{SM} \\
(\%)\end{array}$ & $\begin{array}{c}\mathrm{BD} \\
\left(\mathrm{g} \mathrm{cm}^{-3}\right)\end{array}$ & $\begin{array}{c}\mathrm{SOM} \\
\left(\mathrm{g} \mathrm{kg}^{-1}\right)\end{array}$ & $\begin{array}{c}\mathrm{TN} \\
\left(\mathrm{g} \mathrm{kg}^{-1}\right)\end{array}$ & $\begin{array}{c}\mathrm{TP} \\
\left(\mathrm{g} \mathrm{kg}^{-1}\right)\end{array}$ & $\begin{array}{c}\mathrm{TK} \\
\left(\mathrm{g} \mathrm{kg}^{-1}\right)\end{array}$ & $\begin{array}{c}\mathrm{AN} \\
\left(\mathrm{mg} \mathrm{kg}^{-1}\right)\end{array}$ & $\begin{array}{c}\mathrm{AP} \\
\left(\mathrm{mg} \mathrm{kg}^{-1}\right)\end{array}$ & $\begin{array}{c}\mathrm{AK} \\
\left(\mathrm{mg} \mathrm{kg}^{-1}\right)\end{array}$ \\
\hline Upper slope & 14.54 & 0.96 & 61.03 & 5.19 & 1.06 & 25.99 & 1046.46 & 20.63 & 231.15 \\
\hline Middle slope & 12.52 & 0.96 & 52.30 & 4.27 & 1.02 & 25.78 & 785.26 & 14.86 & 176.71 \\
\hline Lower slope & 12.82 & 1.01 & 33.27 & 2.98 & 1.00 & 26.40 & 1128.76 & 12.61 & 146.40 \\
\hline Foot slope & 19.55 & 0.83 & 59.03 & 7.31 & 1.15 & 16.33 & 1232.96 & 12.78 & 204.26 \\
\hline$F$-value & $2.25^{\star}$ & $3.17^{\star}$ & $3.16^{\star \star}$ & $2.52^{\star}$ & $2.75^{\star}$ & 1.32 & $2.65^{\star}$ & $2.18^{\star}$ & $2.29^{\star}$ \\
\hline $\begin{array}{c}F \text {-value of interaction } \\
\text { (position/land-use) }\end{array}$ & $4.20 \star \star$ & $3.72^{\star \star}$ & $5.59 \star \star$ & $38.76^{\star \star}$ & $72.00 \star \star$ & $26.17 \star \star$ & $103.22^{\star \star}$ & $10.56^{\star \star}$ & $193.50 \star \star$ \\
\hline
\end{tabular}

${ }^{\star}$ Significant at the $5 \%$ level of probability. ${ }^{\star \star}$ Significant at the $1 \%$ level of probability.

the upper slope position. The equation of PI was expressed as:

$$
P I=\sum_{i=1}^{n}\left(\left(x_{i}-x_{i}^{\prime}\right) / x_{i}^{\prime}\right) \times 100 \% / n
$$

where $x_{i}$ is the value of the soil's physical and chemical properties; $x_{i}^{\prime}$ is the soil properties under upper slope position conditions. The negative value of the $\mathrm{BD}$ difference was used because the higher $\mathrm{BD}$ value usually indicated land deterioration (Lowery et al. 1995).

\section{Results and discussion}

\section{The distribution of soil nutrients and moisture in different land cover types and slope positions}

Among soil properties, SOM was a sensitive indicator of soil quality and could serve as a suitable indicator of soil quality within a narrow range of soil (Murage et al. 2000). Moreover, the soil organic matter fraction may offer further insight into soil fertility changes and the sustainability of past management (Barrios et al. 1996; Kapkiyai et al. 1998).
Table 1 shows that SOM, total nitrogen (TN), BD and available potassium (AK) are significantly different among the different land-use types. Soil organic matter and $\mathrm{TN}$ were lower in farmland than in shrub land and grassland, but BD was higher. The results indicated that cultivation decreased soil nutrient levels, which had been noted by many authors (Davidson \& Ackerman 1993; Lepsch et al. 1994; Ellert \& Gregorich 1996). Organic matter in cultivated soils has less physical protection than that in the uncultivated soils because of the removal of large quantities of biomass during land clearing, a reduction in the quantity and quality of organic inputs to the soil and increasing soil organic matter decomposition rates. These higher decomposition rates are due to enhanced biological activity caused by soil mixing from tillage and higher temperatures from increased soil exposure (Barber 1995). Also tillage periodically breaks up macro-aggregates and exposes previously protected organic matter in soil macro-aggregates (Nardi et al. 1996). Conditions under the shrubs are suitable for SOM accumulation because shrubs often have the largest layer coverage and lower light penetration. Also shrub land usually decreases runoff (Jiang et al. 1996; Dong et al. 1998) and deposits part of the dissolved 
soil matter in runoff. Therefore, it has higher soil nutrient contents. Total nitrogen showed the same results in ANOVA and comparisons for four land uses (Table 1). This similarity may be related to SOM influencing nutrient retention and supply (Brubaker et al. 1993). Unlike SOM and TN, there was no significant difference for other soil nutrients among these land uses. No difference of total phosphorous (TP) among land uses may be due to the inactive nature of $\mathrm{P}$ (Chen \& Zhang 1991). But a remarkable feature was that TP, TK, available nitrogen (AN), available phosphorous (AP) and $\mathrm{AK}$ showed lower values in cultivated land or reforested land and higher values in shrub land. The results indicated that land-use changes influence soil nutrient processes and human disturbance could cause soil nutrient loss (Fu et al. 2000).

Pierson and Mulla (1990) found that soils on foot slope and toe slope positions had a higher SOM content, greater aggregate stability, and lower clay content than those on summit positions. Malo et al. (1974) reported that organic $\mathrm{C}$ content, clay content, and surface thickness increased from the shoulder position to the foot slope. Similar results were observed for prairie soils in Canada (Gregorich \& Anderson 1985). Table 2 shows that soil nutrients of different slope positions were different, but the variability was too high for statistical significance. Close observation suggested that
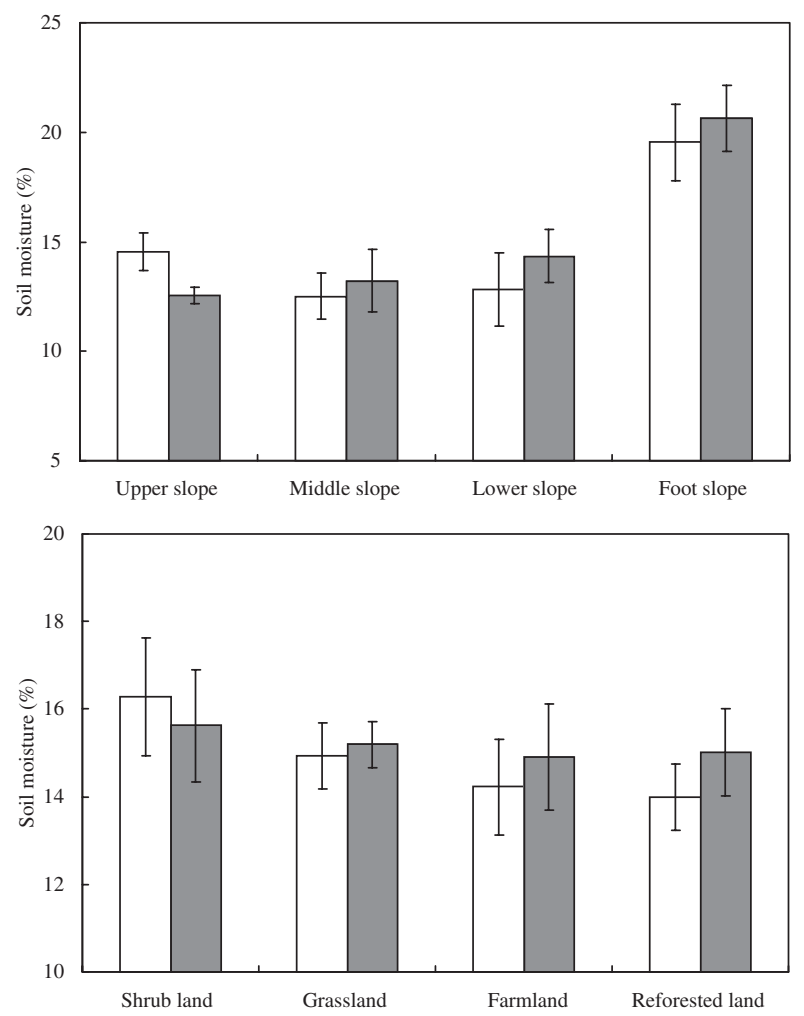

Fig. 2. Patterns of variation in soil moisture in relation to different land covers and slope positions. ( $\square$ ) $0-20 \mathrm{~cm}$; (口) $20-40 \mathrm{~cm}$. there was a tendency for greater values in nutrients at the top slope and foot slope. Higher nutrient contents on the foot slope may result from deposition of nutrients from other positions (Brubaker et al. 1994).

Table 2 also give the results of the test for interactions of the land cover and slope positions by multivariate ANOVA. The $F$-value indicates that the selected soil properties show very significant due to the combined effects of land cover and slope position. The results also show that interaction of land cover and slope position imposed great influence on the soil nutrient change after the deforestation. The effect of interaction on soil nutrients was larger than that of one factor.

Soil moisture is a variable factor that is subject to site conditions. The mean soil moisture content in $0-$ $20 \mathrm{~cm}$ of the shrub land, grassland, farmland and forest land soils was $16.28 \%, 14.93 \%, 14.23 \%$ and $13.98 \%$, respectively. The soil moisture of shrub land was greater than that of other land covers. Because the shrubs usually had the highest layer coverage, richness and lower light penetration, the infiltration and evaporation of the soils under shrubs was weaker than in other land covers. Fu et al. (2000) pointed out that although the values at the surface of the land showed little difference, there were larger variations in the deeper layer of soils. The average soil moisture contents of the top slope, middle slope, lower slope and foot slope were $14.54 \%, 12.52 \%, 12.82 \%$ and $19.95 \%$, respectively (Fig. 2). The soil water content is related to the angle of the slope as well as to the cultivation measures. In this study the foot slope was almost flat and its water content was significantly larger than other slopes. Our results show that patterns and responses of soil nutrients and water vary according to slope position and land cover type.

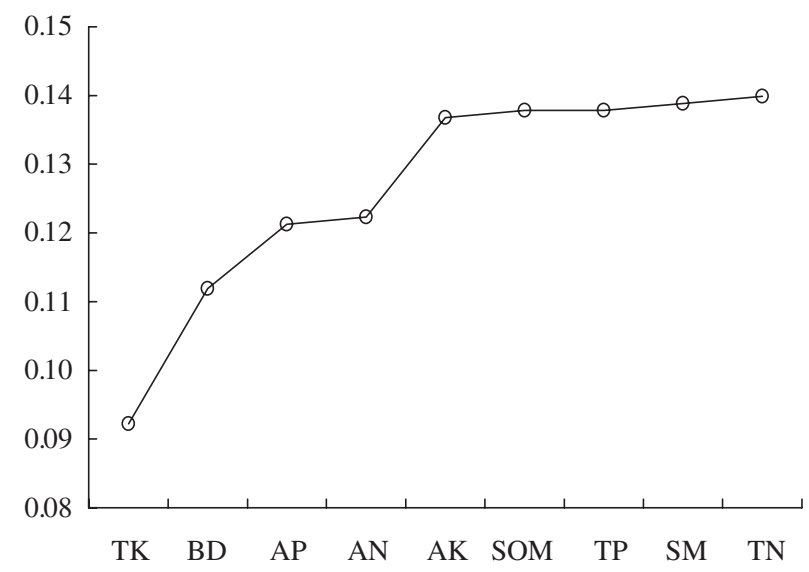

Fig. 3. Values of weights of different soil quality factors. (-○-) Weight of soil factors. AK, available potassium; AN, available nitrogen; $\mathrm{AP}$, available phosphorus; $\mathrm{BD}$, bulk density; $\mathrm{SM}$, soil moisture; SOM, soil organic carbon; TK, total potassium; TN, total nitrogen; TP, total phosphorus. 


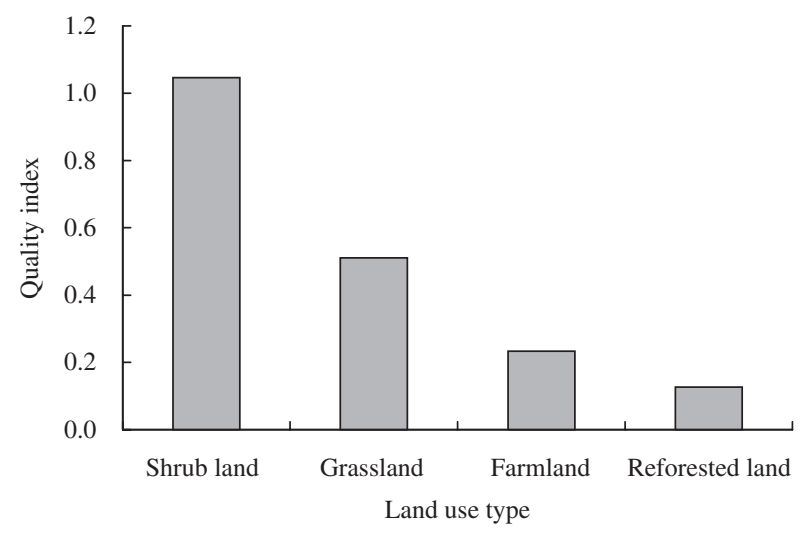

Fig. 4. Soil quality index $(Q I)$ of different land-use types.

\section{Soil quality characteristics under different land cover types}

Previous studies have concentrated on single soil property evaluations, such as, changes in soil organic matter, $\mathrm{N}, \mathrm{P}$ and $\mathrm{K}$, and much less attention has been paid to a comprehensive assessment of soil quality changes (Wang \& Gong 1998). The results form different researchers are difficult to compare because of the different benchmark soils they used, and therefore, the rate of soil change cannot be accurately assessed and compared.

Due to a large number of physical and chemical indicators of soil, many methods have been proposed to integrate the factors and quantify soil quality (Adejuwon \& Ekanade 1988; Wang \& Gong 1998). The calculated integrated soil quality index $(Q I)$ reflects the relative soil quality degree of different land cover types. The membership values $Q\left(x_{i}\right)$ of each soil quality factor under different land cover types were calculated with equations 2 and 3 (Table 1). Figure 3 shows the weights of the soil quality factors $\left(W_{i}\right)$ calculated with equation 4. $W_{i}$ was calculated by the first component capacity scores due to their cumulative percentage had reached $81.8 \%$. The integrated quality index ( $Q I)$ was further derived from equation 1.

Figure 4 showed the $Q I$ values of different land cover types. The values for shrub land, grassland, farmland and reforested land were 1.05, 0.51, 0.23 and 0.13 , respectively. The results clearly showed that the land cover changes had resulted in very different soil quality levels. The $Q I$ values varied greatly from 0.13 to 1.05 and shrub land had the highest value while reforested land exhibited the lowest value.

The reforested land showed the lowest $Q I$ value mainly because of the human disturbance and its lower biodiversity. There is a commonly held belief that reforestation of conifers degrades soil fertility in various ways, although Binkley (1995) concluded that there has

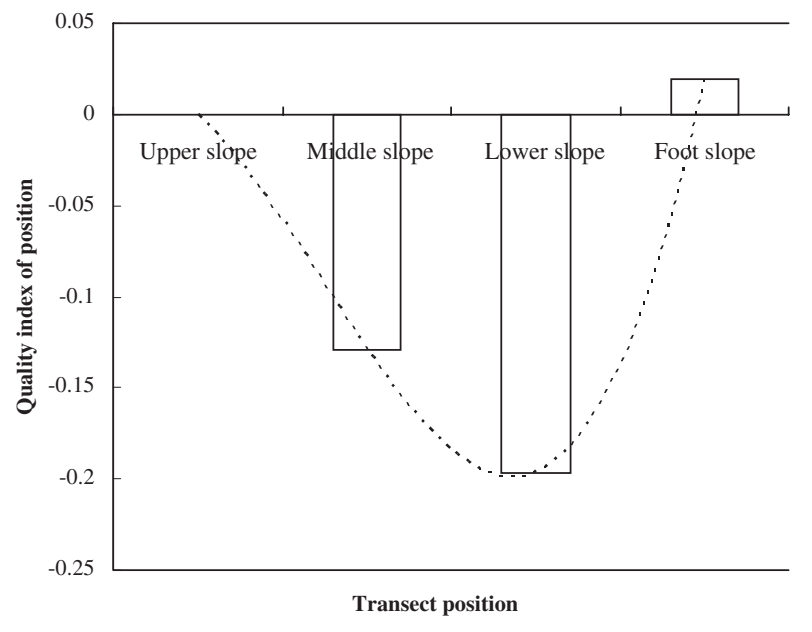

Fig. 5. Soil quality index of position $(P I)$ in relation to the transect positions

been little consistent scientific evidence for this. The results validated again that cultivation could lower soil quality levels. The cultivation of deforested land may rapidly diminish soil quality, as ecologically sensitive components of the previous ecosystem are not able to buffer the effects of agricultural practices. The grassland showed lower $Q I$ value than shrub land mainly because of the grazing activity of animals and human herb collection, which increase soil erosion and nutrient lose. The highest $Q I$ value existed in the shrub land indicating higher soil quality levels. The more complex condition of shrubs might be a reason for this change. The $Q I$ of farmland and reforested land indicated that human disturbance tended to trigger a degradation succession. Shrubs that have high soil fertility levels could be used to restore the soil nutrients as they can decrease soil erosion and improve soil conditions in the ecosystem (Wang et al. 2001).

\section{Soil quality assessment under different slope positions}

The $P I$ value can be regard as an integrated indication of soil deterioration degree in different slope positions. A positive $P I$ value indicates improvement of the soil compared with the top slope, whereas a negative PI value indicates deterioration of the soil. The calculated PI reflects the percent change in soil properties compared to the values of the top slope (Fig. 5). Although soil nutrient responses to slope positions were variable depending on land cover types, in our study soils on the lower slope had a significantly lower (i.e. negative) PI $(-19.64 \%)$ than soils in the other positions. The values for the middle slope and the foot slope were $-12.88 \%$ and $1.91 \%$. The PI values were represented by a Ushaped distribution as shown in Fig. 5. 
There is a small village at the foot of the slope. The human disturbance decreased along the slope and there were less human and animal activities in the top and middle slopes. Due to the higher elevation the area of farmland at these positions were also less than on the lower and foot slopes. The soil quality changes along the slope may be partly due to the effects human disturbance on the land cover. But research should be carried out to investigate these relationships further. The foot slope represents the base of the hill and the top, middle, and lower slopes may contribute runoff to the foot slope. Also with the flat landform and less soil erosion in the foot slope, the foot slope had a higher PI value.

\section{Conclusions}

In the Wolong nature reserve secondary succession after forest cutting and human disturbance has caused ecosystem heterogeneity. In this study soils were taken from four typical land cover types (shrub land, grassland, farmland and reforested land) under four slope positions (upper slope, middle slope, lower slope, foot slope) and analyzed to elucidate the soil-land cover type and soil-slope position relationships on the transect scales on the slope.

The results showed that SOM, TN, BD and $\mathrm{AK}$ exhibit significant differences among the different land cover types. The SOM and TN of farmland and reforested land were lower than of shrub land and grassland. The shrub land had the highest levels for most soil nutrients and the farmland showed the lowest values for most soil nutrients. Multivariate ANOvA showed that the variations in soil nutrients are ascribe to their interactions. The soil moisture of shrub land was greater than that of other land covers. Reforested land had the lowest soil water content. Water content at the foot slope was significantly larger than at the other slopes due to the flat landform.

Two integrated quantitative methods were developed to compare soil quality of different land cover types $(Q I)$ and of different slope positions $(P I)$. The results showed that soil quality under four typical land cover types (QI) were: shrub land $>$ grassland $>$ farmland $>$ reforested land. This meant that shrub land had the function of a 'fertility island' on the slope due to is high fertility level and shrub land could be an optional choice to restore the soil properties of the areas where the conditions are suitable for the secondary succession of shrubs. Soil quality under different slope positions (PI) showed that the foot slope and upper slope had the higher soil quality levels compared to the middle slope and lower slope. The reason was that the foot slope had less soil erosion and the top slope had less human disturbance.

At the transect level, land cover and slope position resulted in more complex patterns of soil nutrient distribution. Because the complex nature of nutrient distribution and the effect of human activities originating from increases in population will further intensify land and soil use, future research is needed to more fully understand the interactive relationships among landscape properties, the ecosystem properties, soil erosion, soil nutrients, land-use and its history and management.

\section{Acknowledgements}

This project was supported by National Key Project for Basic Research in China (No. G2000046807), Knowledge Innovation Program in CAS (No. KZCX2-405) and National Natural Science Foundation of China (No. 40171085). We thank the members of our team from Peking University and the Institute of Mountain Hazards and Environment, Chinese Academy of Sciences for help with soil sampling and vegetation investigation. We thank Dr SunKee Hong at Seoul National University for his useful suggestions on this paper and also for this special issue from the 8th INTECOL International Congress of Ecology, Seoul 2002.

\section{References}

Adejuwon J. O. \& Ekanade O. (1988) A comparison of soil properties under different land use types in a part of the Nigerian cocoa belt. Catena 15: 319-331.

An S. Q., Wang Z. F., Zhu X. L., Liu Z. L. \& Hong B. G. (1997) Effects of soil factors on the secondary succession of forest community. Acta Ecologica Sinica 17: 44-50 (in Chinese with English abstract).

Barber R. G. (1995) Soil degradation in the tropical lowlands of Santa Cruz, Eastern Bolivia. Land Degradation and Rehabilitation 6: 95-107.

Barrios E., Buresh R. J. \& Sprent J. I. (1996) Organic matter in soil particle size and density fractions from maize and legume cropping systems. Soil Biology and Biochemistry 28: 185-193.

Benning T. L. \& Seastedt T. R. (1995) Landscape-level interactions between topoedaphic features and nitrogen limitation in tallgrass prairie. Landscape Ecology 10: 337-348.

Binkley D. (1995) The influence of tree species on forest soils processes and patterns. In: Proceedings of the Trees and Soils Workshop (eds D. J. Mead \& I. S. Cornforth) pp. 1-34. Lincoln University Press, New Zealand.

Brubaker S. C., Jones A. J., Frank K. \& Lewis D. T. (1994) Regression models for estimating soil properties by slope positions. Soil Science Society of America fournal 58: 17631767.

Brubaker S. C., Jones A. J., Lewis D. T. \& Frank K. (1993) Soil 
properties associated with slope positions. Soil Science Society of America fournal 57: 235-239.

Chen H. \& Zhang S. (1991) Nitrogen and phosphorus movement from loess tillage under modeling the rainfall-runoff erosion processes. Scientia Geographica Sinica 11: 142-148 (in Chinese with English abstract).

Davidson E. A. \& Ackerman I. L. (1993) Changes of soil carbon inventories following cultivation of previously untilled soils. Biogeochemistry 20: 161-193.

Dong R., Zhu X., He Z., Wan T. \& Wang X. (1998) Laws of soil erosion in loess hilly and gully region of Dingxi prefecture. Bulletin of Soil andWater Conservation 18: 1-15 (in Chinese with English abstract).

Editorial Committee. (1996) Soil Physical and Chemical Analysis and Description of Soil Profiles. Standards Press of China, Beijing (in Chinese).

Ellert B. H. \& Gregorich E. G. (1996) Storage of carbon, nitrogen and phosphorus in cultivated and adjacent forested soils of Ontario. Soil Science 161: 1-17.

Fao-Unesco. (1988) Soil map of the world, revised legend. World Soil Resources Report 60. FAO: Rome.

Fu B. J., Chen L. D., Ma K. M., Zhou H. F. \& Wang J. (2000) The relationships between land use and soil conditions in the hilly area of the loess plateau in northern Shaanxi, China. Catena 39: 69-78.

Fu B. J., Guo X. D., Chen L. D., Ma K. M. \& Li J. R. (2001) Soil nutrient changes due to land use changes in Northern China $\mathcal{f}_{-}$a case study in Zunhua County, Hebei Province. Soil Use and Management 17: 294-296.

Fu B. J., Ma K. M., Zhou H. F. \& Chen L. D. (1999) The effect of land use structure on the distribution of soil nutrients in the hilly area of the loess plateau, China. Chinese Sciences Bulletin 44: 732-736.

Gregorich E. G. \& Anderson D. W. (1985) Effects of cultivation and erosion on soils of four top sequences in Canadian prairies. Geoderma 36: 343-354.

Jamalam L., Tamaluddin S., Hiroyo N. \& Ali K. M. (1998) Deterioration of soil fertility by land use changes in South Sumatra, Indonesia: from 1970 to 1990 . Hydrological Process 12: 20032013.

Jiang Z., Wang Z. \& Liu Z. (1996) Quantitative study on spatial variation of soil erosion in a small watershed in the loess hilly region. Fournal of Soil Erosion and Soil and Water Conservation 2: 1-9 (in Chinese with English abstract).

Kapkiyai J. J., Karanja N. K., Woomer P. L. \& Qureshi J. N. (1998) Soil organic carbon fractions in a long-term experiment and the potential for their use as a diagnostic assay in highland farming systems of Central Denya. African Crop Science Fournal 6: 1928.

Kosmas C., Gerontidis S. \& Marathianou M. (2000) The effect of land use change on soils and vegetation over various lithological formations on Lesvos (Greece). Catena 40: 51-68.

Lepsch I. F., Menk J. R. F. \& Oliveira J. B. (1994) Carbon storage and other properties of soils under agriculture and natural vegetation in Sao Paulo State, Brazil. Soil Use and Management 10: $34-42$.

Li M. B. \& Zhang X. W. (1991) The assessment of soil fertility. In: Soil Fertility Progress (ed. X. W. Zhang) pp. 221-234. Chinese Science and Technology Press, Beijing (in Chinese).

Liu S. L., Fu B. J., Lü Y. H. \& Chen L. D. (2002) Effects of reforestation and deforestation on soil properties in humid mountainous areas: a case study in Wolong nature reserve, Sichuan province, China. Soil Use and Management 18: 376-380.

Lowery B., Swan J., Schumacher T. \& Jones A. (1995) Physical properties of selected soils by erosion class. Fournal of Soil and Water Conservation 50: 306-311.

Malo D. D., Worcester B. K., Cassel D. K. \& Matzdorf K. D. (1974) Soil-landscape relationships in a closed drainage system. Soil Science Society of America Fournal 38: 813-818.

Moran E. F., Brondizio E. S., Tucker J. M., Silva-Forsberg M. C., Mccracken S. \& Falesi I. (2000) Effects of soil fertility and land-use on forest succession in Amazo Ãnia. Forest Ecology and Management 139: 93-108.

Murage E. W., Karanja N. K., Smithson P. C. \& Woomer P. L. (2000) Diagnostic indicators of soil quality in productive and non-productive smallholders' fields of Kenya's Central Highlands. Agriculture, Ecosystems and Environment 79: 1-8.

Nardi S., Cocheri G. \& Dell A. G. (1996) Biological activity of humus. In: Humic Substances in Terrestrial Ecosystems (ed. A. Piccolo) pp. 361-406. Elsevier, Amsterdam.

Nelson D. W. \& Sommers L. E. (1975) A rapid and accurate method for estimating organic carbon in soil. Proceedings of the Indiana Academy of Science 84: 456-462.

Parkinson J. A. \& Allen S. E. (1975) A wet oxidation procedure suitable for determination for nitrogen and mineral nutrients in biological material. Communications in Soil Science and Plant Analysis 6: 1-11.

Pierson F. B. \& Mulla D. J. (1990) Aggregate stability in the Palouse region of Washington: effect of slope position. Soil Science Society of America fournal 54: 1407-1412.

Townsend A. R., Vitousek P. M. \& Trumbore S. E. (1995) Soil organic matter dynamics along gradients in temperature and land use on the island of Hawaii. Ecology 76: 721-733.

Wang X. (1994) Application of soil taxonomic classification in the evaluation of soil resources. In: Recent Treatises on Chinese Soil Taxonomic Classification (ed. Z. Gong) pp. 475-481. Science Press, Beijing (in Chinese).

Wang J., Fu B. J., Qiu Y. \& Chen L. D. (2001) Soil nutrients in relation to land use and slope position in the semi-arid small catchment on loess plateau in China. Fournal of Arid Environments 48: 537-550.

Wang X. \& Gong Z. (1998) Assessment and analysis of soil quality changes after eleven years of reclamation in subtropical China. Geoderma 81: 339-355.

Zhang Q. F., Song Y. C. \& You W. H. (1999) Relationship between plant community secondary succession and soil fertility in Tiantong, Zhejiang province. Acta Ecologica Sinica 2: 174179 (in Chinese with English abstract). 